http://jgarmianuniv.net

https://doi.org/10.24271/garmian.64

\title{
Evaluation of Water Quality and Performance for a Water Treatment Plant: Khanaqin City as a Case Study
}

\author{
Hayder Mohammed Issa \\ College of Human Sciences, University of Garmian \\ E-mails: dr.hayder.issa@gmail.com, hayder.mohammed@garmian.edu.krd
}

\begin{abstract}
Treatment or purification of water is considered as a critical challenge especially in developing countries since this treatment is an essential facility to conserve the public health and environment by eliminating of waterborne diseases and pathogens. This study was made to assess the efficiency of Khanaqin City water treatment plant (KCWTP) which is the main source to supply drinking water in Khanaqin City, and to evaluate the treated water quality that reached to city residents. Khanaqin City water treatment plant (KCWTP) consists of conventional water treatment units like other treatment plants in Iraq of flocculation, sedimentation, filtration, and disinfection. These treatments have been studied depending on the collected information and tests.

In this research, several physicochemical and bacteriological parameters of both the raw and treated water were sampled and studied according to Standard Methods and Procedures to evaluate the performance and quality of treated water from Khanaqin City Water Treatment Plant (KCWTP). The results indicated that the source raw water is moderately of poor quality, while the treated water is relatively satisfactory. The treatment process units in KCWTP were also evaluated. Overall removal efficiency of water turbidity in KCWTP is $97.88 \%$. The study suggests that the KCWTP units and process operation need to be improved, rescaled, and redesigned to enhance the plant efficiency and reduce the possibilities of waterborne diseases and contamination that may occur in future in Khanaqin City drinking water.
\end{abstract}

Keywords: Performance, Evaluation, Water treatment plant, Khanaqin City

\section{Introduction}

Water is considered as the most essential element on earth for all kinds of living creatures to maintain their life. In mean time with rapid urban and rural expansion, the demand for water supply has increased many times as a result of more water has been used in domestic, agriculture and industrial sectors [1]. Therefore water is an important natural resource in the world, and life cannot exist and most industries could not operate without water [2]. Providing safe and reliable source of water is thus an essential prerequisite for the establishment of a stable community $[3,4]$. 
Provision of safe drinking water to the people is very essential as up $80 \%$ of all sickness in the world are caused by poor sanitation or unavailability of safe water according to World Health Organization $[5,6]$

It is very necessary to treat water to purify water sources and make them suitable for human consumption through the removal and killing of pathogenic organisms and remove the taste, smell, and other undesirable chemical and physical constituents [7]. Various treatment processes are used to take out impurities from raw water, these processes may be arranged in a treatment sequence of flocculation, sedimentation, filtration, and disinfection for water [8].

Aluminum based coagulants mostly known as alum such as aluminum sulfate $\left(\mathrm{Al}_{2}\left(\mathrm{SO}_{4}\right)_{3}\right)$ are regularly used in drinking water treatment to remove the particulate, colloidal, and other dissolved substances like heavy metals during flocculation process [9]. Heavy metals are considered to be a serious threat to the environment and human health all over the world [10].

In the conventional flocculation -filtration treatment process, suspended solids and natural organic matter are removed from the raw water supply by the addition of coagulants, resulting in the production of water treatment residuals [11]. One of the purification stages is filtration, solids separation from fluids water by using physical or mechanical technique to introducing a medium through which only the water can pass through [12].

In disinfection stage, usually a chlorination process is implemented at most of the water treatment plant, and it is supplied to the public via distribution network, where the dissolved chlorine in drinking water is preferred as a chemical in many countries due to its low cost and effectiveness [13]. Many biological factors are used as bacterial indicators for water treated by disinfection process such as total Coliform, fecal Coliform, fecal streptococci, and Escherichia coli [14]. Disinfection by chlorination is the most important step in water treatment for public supply as chlorine remains in the water as long as it is not consumed. However, chlorine also reacts with the natural organic matter present in the water and produces a number of by-products with harmful long-term effects [15]. During the disinfection process using chlorine, this disinfectant used in the drinking water treatment may convert soluble organic substances to harmful disinfection by-products including trihalomethanes [16].

Numerous compounds such as pharmaceuticals, detergent degradates, flame retardants, plasticizers, polycyclic aromatic hydrocarbons, fragrances, pesticides and an insect repellent, and plant and animal steroids were found in residuals that accumulated from water samples collected after clarification, disinfection (chlorination), and filtration [17].

The performance of each treatment process in a water treatment plant WTP is important and needs to be evaluated to ensure the unit's performance is successful, for this purpose many factors have been applied such as variability in source water 
quality or units operational and technical conditions to ensure that the performance of each unit is satisfactory [18].

The assessment of the technical condition needs to be considered comprehensively both in structural and technical terms and in operational and technological terms while it is necessary to take into account the quantity and the quality of the produced water [19].

In evaluation of a water treatment plant WTP depending on treatment process efficiency, all involved processes could be assessed or a key unit is chosen to decide whether the plant operates in acceptable way or not. Wei et al. [20] have selected the disinfection unit to evaluate a water treatment plant WTP. However, many works evaluated the performance for WTP by assessing whole treatment units starting from screening unit if exist till disinfection or chlorination unit in the plant to approve whether the WTP has satisfactory performance or not like [21-23]. In another trend, WTP may also be evaluated through testing water quality produced in these treatment units that applied in various conventional treatment plants. Identifying water quality parameters is varying due to water sources used in these WTP $[24,25]$. Generally physicochemical are taken as key parameters to classify the quality of both raw and treated waters in any water treatment plant, whereas in other studies biological parameters of treated water were included [26]. In Iraq, conventional water treatment plants WTP are mostly the plants used to supply drinking water in big and small cities. Various studies were performed to investigate the performance of these WTP by assessing the quality of treated water and efficiency of treatment units inside WTP. Several of these studies have focused on water treatment process evaluation $[7,27,28]$. Other studies chose water quality as physicochemical parameters of treated water to assess the efficiency of WTP in a number of Iraqi cities [27, 29-31]. Biological parameters for treated water quality were taken in account as additional factors concerning water treatment plant performance and efficiency in diverse studies in Iraqi WTP [32, 33]. In few works on WTP performance in Iraq, the evaluation was based on the efficiency of specific contaminant removal from raw water such as Polycyclic Aromatic Hydrocarbons [34].

The aim of this study is to evaluate the performance for purification units of a water treatment plant located at Khanaqin City and the quality of raw and treated water of this concerned plant in order to understand the compliance and agreement range of water treatment performance at Khanaqin City by KCWTP with the national and international guidelines and standards. Since no or quite rare previous works have been made to cover this important issue that related to the public health and the environment of Khanaqin City. Also to explore the possibilities to provide a clean water to city residents with less routine maintenance requirements.

\section{Material and Methods}




\subsection{Khanaqin City Water Treatment Plant (KCWTP)}

\subsubsection{Plant Description}

Khanaqin city water treatment plant (KCWTP) provides potable water for most quarters of the city, this city is located east of Iraq is situated in Diyala province, near the border with Iran, its geographical coordinates are $34^{\circ} 20^{\prime} 49^{\prime \prime}$ North, $45^{\circ}$ 24' 2" East. KCWTP serves more than 80000 consumer in the city, by supplying treated water for 8 hours a day as an intermittent system. The plant was constructed in 1968 in Khanaqin City, it was designed to serve a small city at that time as shown in figure1, a photo made by Microsoft Maps program. The capacity of the plant is $22000 \mathrm{~m}^{3} / \mathrm{d}$. Raw water entering KCWTP from intake pipes located in a nearby channel that is fed by Alwand river from the south of the city and from Balajo channel that comes from Sirwan River $24 \mathrm{~km}$ away from the north of the city. The plant didn't have any expansion since first construction, but many maintenance had happened to the plant, the last one was in February 2017, where the old cast iron pipes sedimentation tank were changed.

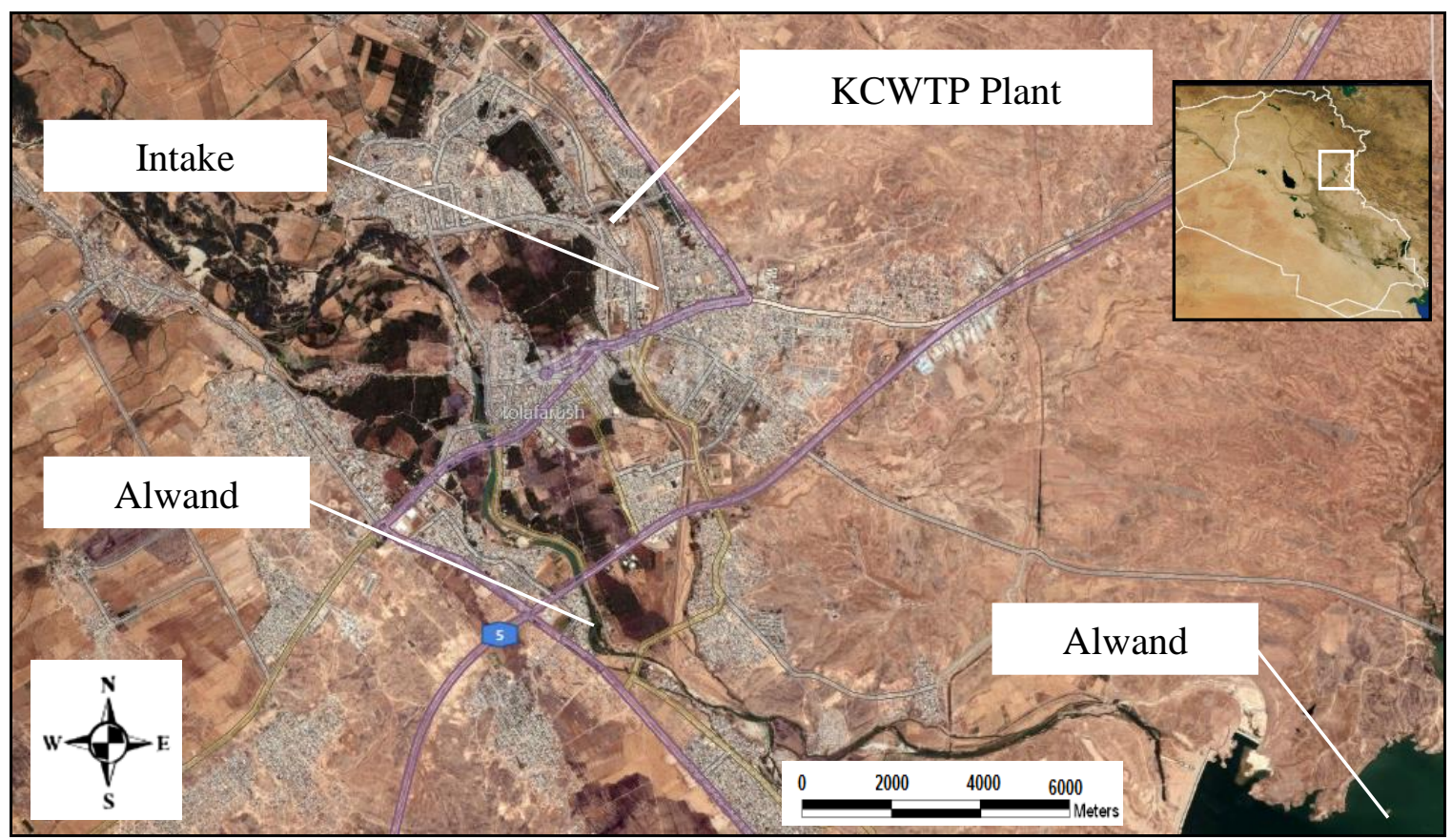

Figure 1. Aerial view for Khanaqin City and locations of water sources and KCWTP.

\subsubsection{Process Description}

The plant is constructed as a conventional water treatment plant, where five essential processes were applied starting from rapid mixing and ending with disinfection. The KCWTP plant location is illustrated in figure 2, taken from Microsoft Maps program. KCWTP stages and facilities are described as follows 


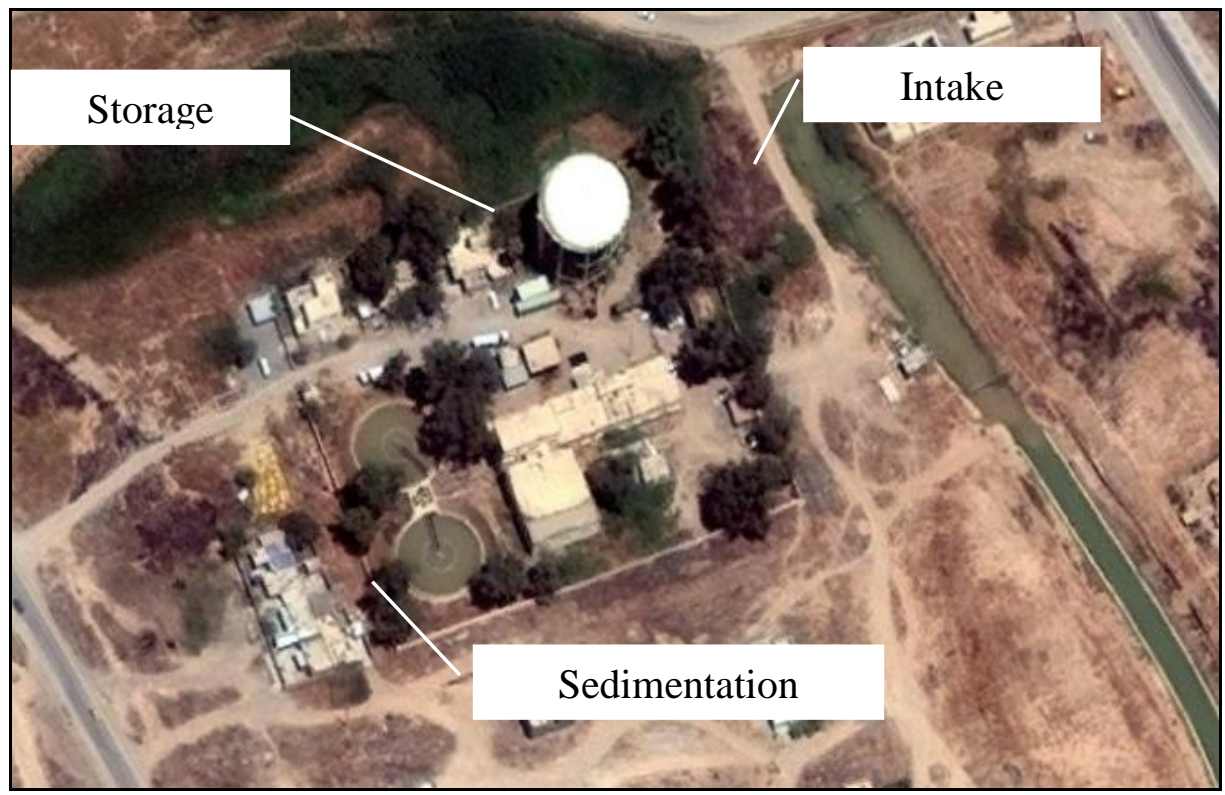

Figure 2. Aerial view of KCWTP sections

Intake: A bar screen and two pipes each of $400 \mathrm{~mm}$ collect raw water to the plant from nearby channel as demonstrated in figure 2 . The draw of intake water is made by two pumps of $2 \mathrm{HP}$.

Rapid mixing: Is the first treatment for incoming raw water. In this stage alum (aluminum sulfate) is added at highest mixing speed, mixing by hydraulic power to the flow of water. The raw water is coagulated continuously with alum in flash mixer tank with a specific retention time.

Flocculation and Sedimentation: The turbid water is directed to flow through the two clay-flocculation basins made of reinforced concrete of $25 \mathrm{~m}$ diameter of each clarifier and $6 \mathrm{~m}$ diameter of inner flocculater (See figure 3). The flocculation is held in the two basins, turbid inlet water is mixed with aluminum at the bottom of the basin, then the water goes into the sintering or coagulation after a period of time of 40 - 60 minutes and then to the sedimentation basins with the period of $(1-1.5)$ hours. The amount of added alum at this stage is $50 \mathrm{~kg} / \mathrm{day}$. 


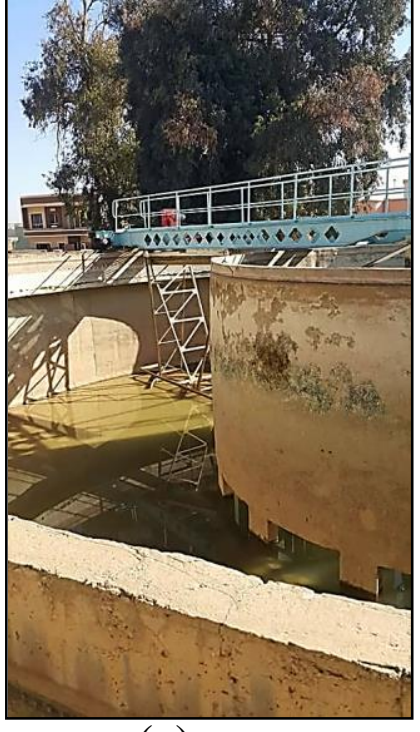

(a)

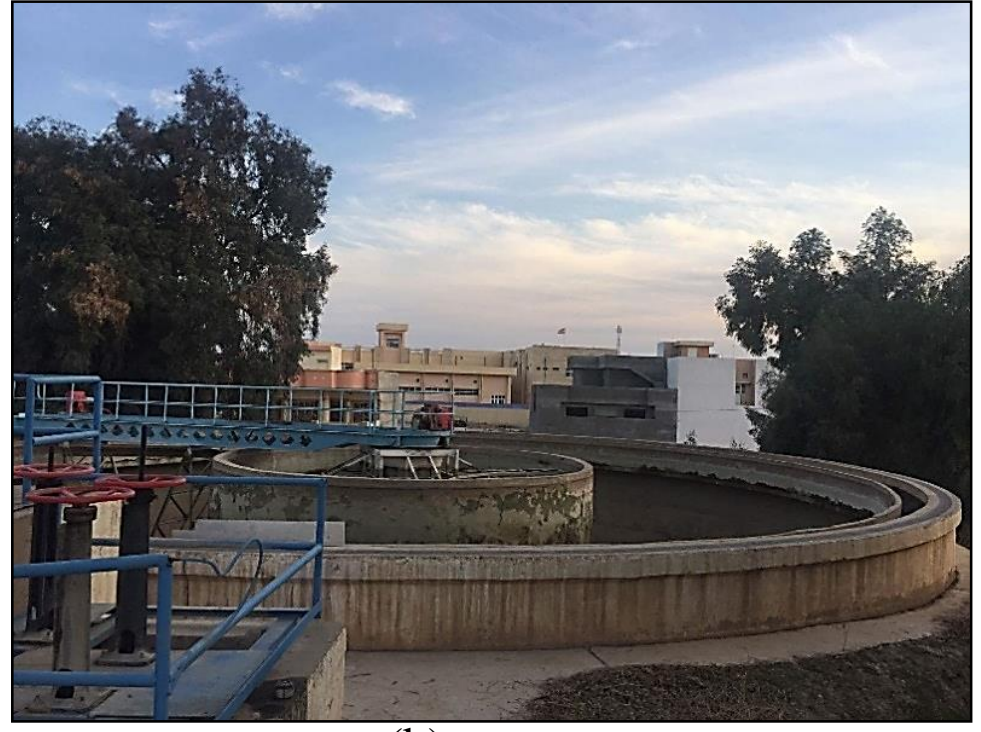

(b)

Figure 3, ( $\mathrm{a}$ and $\mathrm{b}$ ). Flocculation - Sedimentation basin at KCWTP

Sand Filtration: Water is pumped from the sedimentation basins to 8 sand filters, the water inlet from these filters is relatively has a high turbidity. the water arrives to several rapid filters. The dimension of each filter is $5 \mathrm{~m} * 4.5 \mathrm{~m} * 1.7 \mathrm{~m}$. Where the retention time in the filters is $2.5 \mathrm{hr}$ and the surface loading filtration rate of the filters is $978 \mathrm{~m}^{3} / \mathrm{m}^{2} / \mathrm{d}$ was maintained at higher loading rate limit.

Disinfection: After filtration stage, the water passes to the disinfection room located behind filters. Here, the chlorine is added before the storage and distribution of treated water. Lowest chlorination is applied, about (40-55) kg/day of chlorine is added during this process.

Storage and other Facilities: KCWTP is equipped with an elevated water storage tank with limited capacity (See figure 4). The plant contains also secondary buildings, stores, water distribution pumping units and other parts.

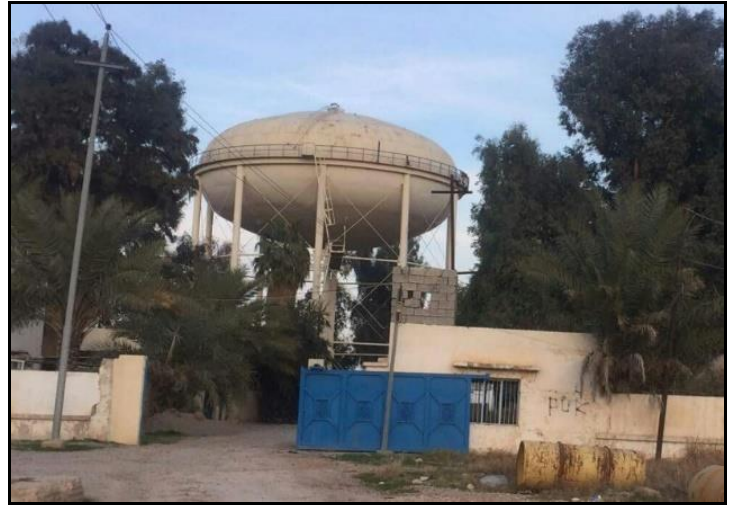

Figure 4. Elevated water storage tank at KCWTP 


\subsection{Field Observation and Sampling Data Collection}

Most of raw and treated water quality data were obtained from Khanaqin Water Directorate. The data samples were collected by them according to routine procedures reference laboratory water and wastewater treatment (standard method). Another set of water quality samples was collected by the author like TDS for raw and treated water during one month in March - April. Statistical analysis made in this study was done by applying advanced Microsoft Excel 2013 software.

\subsection{Plant Efficiency Evaluation Method}

The performance of sedimentation stage and filtration stage in KCWTP are evaluated as a removal efficiency between the turbidity of the raw water and treated water turbidities in the treatment plant [35]. The calculation is a percentage removal as the following equation

Removal Efficiency $\%=$

$\frac{\text { Turbidity in raw water }- \text { Turbidity in treated water }}{\text { Turbidity in raw water }} \times 100 \%$

\subsection{Plant Capacity Assessment Methods}

\subsubsection{Population Estimation}

Water treatment plant (WTP) capacity is always based on the real population of the city being served. In our case, to estimate the needed capacity of KCWTP, it is necessary to know the existing population number of Khanaqin City and also predicting the population number at least within the next ten years to ensure continuous water supply for the near future without any shortages. The population forecasting method that used in this study is the geometric method as follows [36].

$P_{n}=P_{0}(1+r)^{n}$

Where,

$\mathrm{n}$ : Number of time interval

$\mathrm{P}_{\mathrm{n}}$ : population after $\mathrm{n}$ of intervals

$\mathrm{P}_{0}$ : last population 


\subsubsection{Domestic and Urban Water Consumption Estimation}

Water demand is varying with time, for example, water use was increased six times between the years 1900 to 1995 in the world. Nowadays an amount of $220 \mathrm{lpd}$ (liters per person.day) is considered globally an average rate for urban water use, but this water use per capita exceeds $400 \mathrm{lpd}$ in some mega cities in Europe and North America [37]. However, some countries are able only to provide a minimum water supply in the range of $4-30$ lpd such as Gambia and Nigeria in Africa [38].

For middle east region, where a water shortage problem exist, a rate of $1000 \mathrm{lpd}$ of freshwater per capita is considered an distinguishable level. Many countries with water scarcity in this region like Yemen and Eygpt didn't reach this level [39]. In Iraq, the average annual water consumption for domestic and urban uses is about $200 \mathrm{lpd}$ [40]. In this study, an average water demand per capita of $280 \mathrm{lpd}$ was taken as an acceptable value that meets the essential and indispensable needs for human in daily activities.

\subsection{Flocculation and Sedimentation Basin Performance Assessment Method}

The performance of KCWTP and flocculation - sedimentation process were evaluated by comparing the actual existing design dimensions and capacity with the required capacity of treated water supply after about 50 years from the first construction of KCWTP in 1968. Three different conditions were compared in this study to evaluate the flocculation and sedimentation basin performance; first, an optimal design condition based on the actual need for potable water at Khanaqin City. Second, a designed performance calculation based on existing basin dimensions. Third, an actual performance and outlet water of the basin. The design calculations were made in depending on standard design and operation calculations for a conventional water treatment plant $[41,42]$.

\subsection{Filtration Process Performance Assessment Method}

The performance of KCWTP and filtration process were also evaluated by comparing the actual existing design dimensions and capacity with the required capacity of treated water supply after 50 years from the of first construction of KCWTP in 1968 same as the assessment of flocculation and sedimentation basin performance. The assessment was made on the same concepts of design criteria mentioned in previous section. The allowable design number of sand filters to be used was calculated by following relation 
$N=0.044 \sqrt{F}$

Where,

F: treated water flow rate $\left(\mathrm{m}^{3} / \mathrm{d}\right)$

$\mathrm{N}$ : number of sand filters

\section{Results and Discussion}

\subsection{Removal Efficiency and Comparison with Allowable Standards}

It is very hard to evaluate a WTP within short time, to have more adequate decision it needs long time monitoring for WTP performance. In this study, the evaluation was made for short time duration, approximately one month of March - April 2017. Results for averaged raw water and treated water turbidities of KCWTP with removal efficiency of water turbidity and its agreement with various standards are shown in Table 1. The removal efficiency of KCWTP of water turbidity was calculated by using equation 1 .

Table 1. Raw and treated water turbidities, removal efficiency of KCWTP and compliance with most important standards.

\begin{tabular}{|c|c|c|c|c|c|c|}
\hline $\begin{array}{l}\text { Raw } \\
\text { Water } \\
\text { Turbidity } \\
\text { (NTU) }\end{array}$ & $\begin{array}{c}\text { Treated } \\
\text { Water } \\
\text { Turbidity } \\
\text { (NTU) }\end{array}$ & $\begin{array}{l}\text { Removal } \\
\text { Efficiency }\end{array}$ & $\begin{array}{c}\text { Iraqi } \\
\text { Standard }\end{array}$ & Standard & $\begin{array}{l}\text { US.EPA } \\
\text { 30-day } \\
\text { Standard } \\
\text { (1 NTU) }\end{array}$ & $\begin{array}{c}\text { US.EPA } \\
\text { 2-day } \\
\text { Standard } \\
\text { (5 NTU) }\end{array}$ \\
\hline 260 & 5.5 & 97.88 & $\begin{array}{l}\text { Violated } \\
\text { by } 9 \% \\
\text { excess }\end{array}$ & $\begin{array}{l}\text { Violated } \\
\text { by } 9 \% \\
\text { excess }\end{array}$ & $\begin{array}{l}\text { Violated } \\
\text { by } 81 \% \\
\text { excess }\end{array}$ & $\begin{array}{c}\text { Violated } \\
\text { by } 9 \% \\
\text { excess }\end{array}$ \\
\hline
\end{tabular}

Table 1 illustrates the description of the average turbidity data of the raw and supplied water by KCWTP. The removal efficiency calculated by equation 1 has a value of $97.88 \%$ which is acceptable for the existing working plant facilities and according to the quality of raw water used in the city. 
According to the Iraqi, World Health Organization WHO, and (2-day) average American standards on drinking water quality, which demand of 5 NTU. From table 1 , the quality of treated water by KCWTP is not in compliance with these standards limit by an excess of more than $9 \%$. The excess in treated water turbidity refers that on the average this standard limit is violated about $9 \%$ higher than its upper limit.

For monthly average American standards on drinking water quality, Referring to table 1, which shows for the 30-day average turbidity readings for KCWTP. The American EPA standard limits on drinking water calls for a maximum of 30-day average of 1 NTU. Based on this standard, it was stated that there is a $81 \%$ excess with this standard for turbidity quality. This means that there is, on the average, about $4.5 \mathrm{NTU}$ for treated water turbidity is higher than the permitted level by this standard.

\subsection{KCWTP Capacity Assessment}

Current KCWTP capacity to supply potable water is surely can not compete the growing population in Khanaqin City, as it was established about 50 years ago. The required capacity for KCWTP was estimated in depending on the contemporary situation of the city using the methods mentioned in the section 2.4. Table 2 illustrates the current and required capacity for KCWTP to provide a potable water for Khanaqin citizens over 24 hours a day. The required capacity was calculated as follows.

The total number of Khanaqin City population according to recent estimation is about 80000 capita. For the proposition of water consumption per capita of 280 1/c.d. (See section 2.4), the required average capacities were calculated on this basis as demonstrated in Table 2. To maintain this water supply for the next ten years equation 2 was used. the geometric method was applied for population growing forecasting of $2.5 \%$ in a year which is the normal population number growing rate in Iraq. The assumed period of plant operation is 10 years. The predicted average and maximum capacities are shown in Table 2. The values in Table 2 show that a major alteration needs to be made in the KCWTP construction to overcome the huge increasing demand on the water supply now and for the next ten years. 
Table 2. Current and Required KCWTP Capacities

\begin{tabular}{ccccc}
\hline $\begin{array}{c}\text { Current } \\
\text { Capacity }\end{array}$ & $\begin{array}{c}\text { Average } \\
\text { Capacity }\end{array}$ & $\begin{array}{c}\text { Maximum } \\
\text { Capacity }\end{array}$ & $\begin{array}{c}\text { Predicted } \\
\text { Capacity }\end{array}$ & $\begin{array}{c}\text { Predicted } \\
\text { Capacity }\end{array}$ \\
$\begin{array}{c}\text { av. Qreq } \\
\left(\mathrm{m}^{3} / \mathrm{d}\right)\end{array}$ & $\begin{array}{c}\text { max.Q } \\
\left(\mathrm{m}^{3} / \mathrm{d}\right)\end{array}$ & $\begin{array}{c}\text { preq } \\
\left(\mathrm{m}^{3} / \mathrm{d}\right)\end{array}$ & $\begin{array}{c}\left(\mathrm{m}^{3} / \mathrm{d}\right) \\
\text { max pre. }\end{array}$ & $\left(\mathrm{m}^{3} / \mathrm{d}\right)$ \\
\hline 22000 & 22400 & 67200 & 28700 & 86000 \\
\hline
\end{tabular}

\subsection{Performance Evaluation for Flocculation and Sedimentation Basin at KCWTP}

In this section, the performance of the flocculation and sedimentation basin at KCWTP was evaluated by comparing between three conditions stated in section 2.5. The summary of the comparison is shown in Tables 3 . The obtained calculated flocculation and sedimentation basin results are for a water treatment plant with required water supply of existing condition and a water treatment plant with predicted condition to maintain a continuous providing a potable water to Khanaqin City for the next ten years. It is quite clear that the current performance for flocculation and sedimentation basins at KCWTP can not deliver the needed quantity and quality of treated water to the next filtration step in the plant. From Table 3 it can be found that present performance of the flocculation and sedimentation basin is not satisfactory as the handled water operating volume in sedimentation basin is not as required to be for the working condition with existing dimensions.

The need to supply the minimum necessary outlet water quantity affected the performance basins, where short and non-appropriate retention time was used. To overcome these obstacles the number of flocculation and sedimentation basins at KCWTP need to be increased and reformed. The design of these basin also needs to be modified to be more suitable for the existing condition of water treatment capacity and quality at Khanaqin city. 
Table 3. Comparison between allowable operation and design characteristics and current, required and predicted characteristics for flocculation and sedimentation basins at KCWTP

\begin{tabular}{|c|c|c|c|c|}
\hline & $\begin{array}{c}\text { Allowable } \\
\text { design } \\
\text { characteristics }\end{array}$ & $\begin{array}{c}\text { Current } \\
\text { basin } \\
\text { characteristics }\end{array}$ & $\begin{array}{c}\text { Required } \\
\text { basin } \\
\text { characteristics }\end{array}$ & $\begin{array}{c}\text { Predicted } \\
\text { basin } \\
\text { characteristic } \\
\text { s }\end{array}$ \\
\hline $\operatorname{SOR}\left(\mathrm{m}^{3} / \mathrm{m}^{2} / \mathrm{d}\right)$ & $20-40$ & $44.8 * *$ & 30 & 30 \\
\hline Oper. sed. vol. $\left(\mathrm{m}^{3}\right)$ & Cap.x 0.125 & $1375 * *$ & 8400 & 10750 \\
\hline Treat. capacity $\left(\mathrm{m}^{3} / \mathrm{d}\right)$ & -- & 22000 & 67200 & 86000 \\
\hline No. of basins (-) & -- & 2 & 4 & 5 \\
\hline Det. time (hr) & $2-4$ & $1-1.5^{* *}$ & 3 & 3 \\
\hline Sed. basin Depth (m) & $3-6$ & $4 *$ & 4 & 4 \\
\hline Outer basin Dia. (m) & Less than 40 & $25 *$ & 32 & 32 \\
\hline Inner basin vol. $\left(\mathrm{m}^{3}\right)$ & Out. basin vol./6 & $242 *$ & 362 & 362 \\
\hline Inner basin dia. (m) & -- & $10 *$ & 13 & 13 \\
\hline Alum Quantity (kg/d) & $30 \mathrm{mg} / \mathrm{l}$ & $50 * *$ & 2000 & 2500 \\
\hline Floc. basin depth (m) & $67 \%$ sed. depth & $3 *$ & 2.7 & 2.7 \\
\hline
\end{tabular}

\subsection{Performance Evaluation for the Filtration Stage at KCWTP}

For the used, rapid sand filters in KCWTP are usually contain a wide pores, especially at the upper filtration layers of hard sand, is used, where particulates and inerts may penetrate these pores easily. The efficiency of these filters is mostly suitable to filtrate high turbidity water quality to catch these undesirable constituents. For the used rapid sand filter in KCWTP, a performance evaluation was performed in this study on the same basis followed with flocculation and 
sedimentation basins. The performance of the filters at KCWTP was evaluated by comparing between three conditions stated in section 2.6. The required number of sand filters was calculated by using equation 3. It was found from Table 4 that the performance of used rapid sand filters is not in satisfactory way. As the filtration rate of $978 \mathrm{~m}^{3} / \mathrm{m}^{2} / \mathrm{d}$ is much higher than the recommended highest allowable filtration ratio of $240 \mathrm{~m}^{3} / \mathrm{m}^{2} / \mathrm{d}$ for rapid sand filters in a conventional water treatment plant. This high filtration rate causes a low treated outlet water quality for filtration step. The remaining design characteristics of the filters are all fall in the recommended limits for these types of sand filters.

For the filtration stage in the water treatment plant comparison between results current, required water supply of existing condition and a water treatment plant with predicted condition to maintain a continuous providing a potable water to Khanaqin City for the next ten years shows a major modification are necessary to enhance the performance of this step to be qualified to contend the increasingly water consumption and demand in the city.

Table 4. Comparison between allowable operation and design characteristics and current, required and predicted characteristics for rapid sand filters at KCWTP

\begin{tabular}{|l|c|c|c|c|}
\hline & $\begin{array}{c}\text { Allowable } \\
\text { design } \\
\text { characteristics }\end{array}$ & $\begin{array}{c}\text { Current } \\
\text { filter } \\
\text { characteristics }\end{array}$ & $\begin{array}{c}\text { Required } \\
\text { filter } \\
\text { characteristics }\end{array}$ & $\begin{array}{c}\text { Predicted } \\
\text { filter } \\
\text { characteristic } \\
\text { s }\end{array}$ \\
\hline $\begin{array}{l}\text { Filtration rate } \\
\left(\mathrm{m}^{3} / \mathrm{m}^{2} / \mathrm{d}\right)\end{array}$ & $120-240$ & $978^{* *}$ & 140 & 140 \\
\hline Total capacity $\left(\mathrm{m}^{3} / \mathrm{d}\right)$ & -- & 22000 & 67200 & 86000 \\
\hline No. of filters $(-)$ & Eq. 3 & $8^{*}$ & 12 & 14 \\
\hline Area each filter $\left(\mathrm{m}^{2}\right)$ & -- & 22.5 & 40 & 1.2 \\
\hline Length/Width & $1-1.4$ & $1.11^{*}$ & 1.2 & 1.7 \\
\hline Filter height (m) & -- & 1.7 & 1.7 & 40 \\
\hline
\end{tabular}

* conformable to design requirement

** unconformable to design requirement 


\subsection{Water Quality}

Treatment processes has removed most of undesirable constituents from raw water, wherein Table 5 it can be found that turbidity and total dissolved solids are mainly removed in KCWTP by sedimentation and filtration processes. Chlorination is applied to disinfect water and to produce the recommended residual reaching the consumer through the distribution systems. The Chlorination in KCWTP has an effective role to sanitize the supplied drinking water to prevent any possibilities of waterborne diseases and contamination that may occur outlet water as shown in Table 5.

Total dissolved solids are actually could not significantly related to treatment efficiency, as some constituents concentration may increase because of the addition of chemicals. Turbidity of raw water was $240-270$ NTU and turbidity of water after treatment was 5.5 NTU as shown in Table 5. Turbidity comes with KCWTP raw water from intake point from nearby channel. The high turbidity may be caused by various suspended solids like clays, sands, silt, organic and inorganic substances, and microorganisms. Turbidity in raw water decreases the efficiency of chlorine for disinfection [43,44]. The turbidity of the treated water as shown Table 5 in the figures did exceed the limit of 5 NTU, which is higher than the Iraqi and WHO drinking specification, even the KCWTP had high percentage removal for turbidity which reached $97.88 \%$.

The $\mathrm{pH}$ parameter is a measurement of the acid-base properties of a solution, where it is a significant indicator for water treatment due to its influences on the dosages of added chemicals to coagulate particles [45]. As shown in Table 5, $\mathrm{pH}$ of the raw water ranged from 6.7 to 7.2 at the intake. The outlet from water treatment plant has a decreased range of $\mathrm{pH}$ of $6.9-7.0$ depending on the amount of coagulants added for suspended solids removal and the chlorine dose used for disinfection. Regularly, with flocculation process, an amount of $\mathrm{CO}_{2}$ is emitted due to the reaction of alum particles with the natural alkalinity of the raw water and hence $\mathrm{pH}$ is lowered, the reaction of chlorine for disinfection will produce free available chlorine which also decreases the $\mathrm{pH}$ [9]. In KCWTP outlet water, $\mathrm{pH}$ was low varied from $6.9-7.0$ as shown in the Table 5 agreed with Iraqi and WHO drinking water specification of $\mathrm{pH}$ in the range 6.5 to 8.5 .

The disinfection stage at KCWTP by chlorination by adding of chlorine. the results of the bacteriological parameter of E. Coli test for raw water were zero as illustrated in Table 5, so no contamination of the intake channel is dictated. For treated water from KCWTP, the same the bacteriological test of E. Coli gave negative results, indicating high disinfecting efficiency. The tests performed for the treated water as recommended in the Iraqi specification. 
The treated water from KCWTP that distributed to the consumer by pipeline network throughout of the city has high levels of residual chlorine as stated in Table 5. The residual chlorine ranged between $1.0-4.0 \mathrm{mg} / \mathrm{l}$ from various sampling points of treated water supply. It decreased to $1.0 \mathrm{mg} / \mathrm{l}$ in the some times and places in the water supply network and increased in other time and places that reached $4.0 \mathrm{mg} / \mathrm{l}$. This increase may indicate contamination of the river and the incidence of a disease-producing organism in the raw water. The importance of residual chlorine is to prevent any contamination in the distribution system that delivers potable water to the city. A level of 0.25 to $0.5 \mathrm{mg} / \mathrm{l}$ is preferred as free available chlorine to ensure disinfected potable water has been reach to all consumers despite any potentials of distribution pipes cracks and contact with various pollution sources. From samples taken from tap water at different locations in the distribution system, significant concentrations of residual chlorine were detected.

Table 5. Some physicochemical and bacteriological parameters in raw and treated water at KCWTP with allowable limits on Iraqi and WHO drinking water standards

\begin{tabular}{|l|c|c|c|c|}
\hline \multicolumn{1}{|c|}{ Parameter } & $\begin{array}{c}\text { Raw } \\
\text { water }\end{array}$ & $\begin{array}{c}\text { Treated } \\
\text { water }\end{array}$ & $\begin{array}{c}\text { Iraqi } \\
\text { Drink. Water } \\
\text { standard }\end{array}$ & $\begin{array}{c}\text { WHO } \\
\text { Drink. Water } \\
\text { standards }\end{array}$ \\
\hline Oudor & Oudor exist & Oudorless & Agreeable & Agreeable \\
\hline Color & Not clear & Colorless & Agreeable & Agreeable \\
\hline $\mathrm{pH}(\mathrm{pH}$ unit) & $6.7-6.9$ & $6.9-7.0^{*}$ & $6.5-8.5$ & $6.5-8.0$ \\
\hline Total dissolved solids $(\mathrm{mg} / \mathrm{l})$ & $480-700$ & $387^{*}$ & 1000 & 500 \\
\hline Turbidity (NTU) & $240-270$ & $5.5^{* *}$ & 5.0 & 5.0 \\
\hline Chlorine (ppm) & 0.0 & $1.0-4.0^{*}$ & $3.0-4.0$ & $<3.0$ \\
\hline E. Coli (100 ml after $24 \mathrm{hr}$ at $\left.44^{\circ} \mathrm{C}\right)$ & Zero & Zero* & $<1.1$ & Zero \\
\hline
\end{tabular}

* Satisfactory to standards

** Unsatisfactory to standards 


\section{Conclusions}

It was found in depending on this extensive investigation made by this study for the performance of khanaqin water treatment plant for a short term observation around two months March - April 2017, the resulting conclusions were obtained

1. The performance of KCWTP Units are relatively satisfactory, the general performance of Khanaqin city water treatment plant was adequately evaluated as well as compared with two conditions; one of actual requirement of current number of population in Khanaqin city, and another of a condition of a water treatment plant that can supply a continuous potable water for the next ten years without any shortage.

2. The removal efficiency of KCWTP has a high ratio, but removal rates of turbidity is not perfectly fulfilled as the suspended particles by flocculation have not been removed by sedimentation. The plant has high efficiency in turbidity removal of $97.88 \%$ and the turbidity of the treated water exceed 5.5 NTU.

3. For 30- day average, turbidity data removal efficiency shows that KCWTP in this study was $81 \%$ exceeds the US.EPA standard, 9\% exceeds Iraqi and WHO Standards.

4. For 2-day average, turbidity data of supplied water show that KCWTP is $9 \%$ exceeds US.EPA standard.

5. The performance of flocculation - sedimentation basin has not efficient operation, the reasons for this the high amounts of turbidity from the intake channel, and the increase in the demand on water supply leads to reduce the detention time in the basin and hence high turbidity in the outlet water turbidity.

6. Rapid sand filters have the same performance difficulties same as sedimentation basin of high water supply demand and limited unit capacity.

7. Values of TDS are high in treated water, appeared to rise due to high turbidity, but still falls in the water classification of acceptable range on Iraqi and WHO standards. It requires to develop useful modifications to control this case.

8. The KCWTP plant is efficient in bacterial removal where chlorination is applied. The residual chlorine in the effluent water from the plant is ranged from 1.0 to 4 $\mathrm{mg} / \mathrm{l}$. This range fulfills the recommended dosage of chlorine of 0.5 in the distribution system.

9. Indispensable continuous maintenance and modifications were found to be obligatory by this precise evaluation of Khanaqin city water treatment plant 
performance to overcome the difficulties accompanied by growing demand on the potable water supply.

\section{Acknowledgments}

The author wishes to express his gratitude to General Directorate of Water/ Khanaqin City, especially the director Engr. Hassan Aghajan Murad for his help in providing the historical and current information about drinking water treatment plant.

\section{References}

1 Al-Jlil, S.A., Alromaih, H., Alshabonah, F., Alsoubaei, F., Alshamary, A., and Hazzazy, H.: 'Evaluation of Performance of Wastewater Treatment Plant at KACST, Riyadh Saudi Arabia', Research Journal of Environmental Sciences, 2014, 8, (2), pp. 117

2 Tebbutt, T.H.Y.: 'Principles of water quality control' (Butterworth-Heinemann, 1997. 1997)

3 Janna, H., and Al-Samawi, A.A.: 'Performance Evaluation of Al-Karkh Water Treatment Plant in the City of Baghdad', International Journal of Advanced Research, 2014, 2, (10), pp. 823-829

4 Reza, R., and Singh, G.: 'Assessment of ground water quality status by using water quality index method in Orissa, India', World Applied Sciences Journal, 2010, 9, (12), pp. 13921397

5 Ibrahim, A., Onyenekwe, P., and Nwaedozie, I.: 'An Efficiency Assessment of Lower Usuma Water Treatment Plant in Abuja Metropolis, Nigeria', Journal of Environmental Science, Toxicology and Food Technology, 2014, 8, (12), pp. 46-53

6 World Health Organization: 'Guidelines for drinking-water quality: recommendations' World Health Organization, 2004.

7 Mohammed, A.A., and Shakir, A.A.: 'Evaluation the Performance of Al-wahdaa Project Drinking Water Treatment plant: A case Study in Iraq', International Journal of Advances in Applied Sciences, 2012, 1, (3), pp. 130-138

8 Angreni, E.: 'Review on optimization of conventional drinking water treatment plant', World Applied Sciences Journal, 2009, 7, (9), pp. 1144-1151

9 Srinivasan, P., Viraraghavan, T., and Subramanian, K.: 'Aluminium in drinking water: An overview', Water Sa, 1999, 25, (1), pp. 47-55

10 Rajeswari, A.: 'Efficiency of effluent treatment plant and assessment of water quality parameters in tannery wastes', European Journal of Experimental Biology, 2015, 5, (8), pp. 49-55

11 Ippolito, J., Barbarick, K., and Elliott, H.: 'Drinking water treatment residuals: a review of recent uses', Journal of Environmental Quality, 2011, 40, (1), pp. 1-12 
12 Hamdy, S.M.A.: 'Examination and Analysis of Water from Household Water Filter System Kifllo, Engineering \&amp; Technology Journal 2016, 34, (3 Part (B) Scientific), pp. 418-424

13 Sharma, H.K., and Rather, M.A.: 'Assessment of Chlorination Efficiency and Quality of Municipal Drinking Water in Gwalior City, Madhya Pradesh, India', International Journal of Science and Research, 2015, 4, (1), pp. 1699-1707

14 Sadik, W.H., and Al-Salman, I.M.: 'Evaluate the efficiency of two water treatment plants of drinking water in City of Kerbala - Kerbala Governance - Iraq ', journal of kerbala university 2014, pp. 1-9

15 Gopal, K., Tripathy, S.S., Bersillon, J.L., and Dubey, S.P.: 'Chlorination byproducts, their toxicodynamics and removal from drinking water', J. Hazard. Mater., 2007, 140, (1), pp. 1-6

16 Zhao, Z.-Y., Gu, J.-D., Li, H.-B., Li, X.-Y., and Leung, K.M.-Y.: 'Disinfection characteristics of the dissolved organic fractions at several stages of a conventional drinking water treatment plant in Southern China', J. Hazard. Mater., 2009, 172, (2), pp. 1093-1099

17 Stackelberg, P.E., Gibs, J., Furlong, E.T., Meyer, M.T., Zaugg, S.D., and Lippincott, R.L.: 'Efficiency of conventional drinking-water-treatment processes in removal of pharmaceuticals and other organic compounds', Sci. Total Environ., 2007, 377, (2), pp. 255272

18 Zhang, K., Achari, G., Sadiq, R., Langford, C.H., and Dore, M.H.: 'An integrated performance assessment framework for water treatment plants', Water Res., 2012, 46, (6), pp. 1673-1683

19 Kučera, T., Tuhovčák, L., and Biela, R.: 'Methodology for the Estimation of the Technical Condition in the Case of Water Treatment Plants', Procedia Engineering, 2016, 162, pp. 71 76

20 Wei, J., Ye, B., Wang, W., Yang, L., Tao, J., and Hang, Z.: 'Spatial and temporal evaluations of disinfection by-products in drinking water distribution systems in Beijing, China', Sci. Total Environ., 2010, 408, (20), pp. 4600-4606

21 Mishera, A., and Kadu, P.: 'Performance Evaluation of Water Treatment Plant at Yavatmal (MS): Case Study', International Journal of Research in Advent Technology, 2014, 2, (5), pp. $455-458$

22 Ali, A., Hashmi, H.N., Baig, N., Iqbal, S., and Mumtaz, K.: 'Performance Evaluation of the water treatment plants of Islamabad-Pakistan', Archive Environmental Science, 2012, 6, pp. $111-117$

23 Ahmadli, Z., Fahiminia, M., Ansari, R., Savadkouhi, M., Anbaz, A., Escandari, A., and Arang Jang, S.: 'Performance Evaluation of Qom Water Treatment Plant during 2005 to 2014', Archives of Hygiene Sciences, 2017, 6, (1), pp. 58-65

24 Alobaidy, A., Maulood, B., and Kadhem, A.: 'Evaluating raw and treated water quality of Tigris River within Baghdad by index analysis', journal of water resource and protection, 2010, 2010, (2), pp. 629-635

25 Eassa, A.M., and Mahmood, A.A.: 'An Assessment of the treated water quality for some drinking water supplies at Basrah', Journal of Basrah Researches ((Sciences)) Volume, 2012, 38, (3) 
26 Varadhajan, R.B.: 'Importance of Biological Parameters of Water Quality to Reform Water Quality Index in Practice', in Editor (Eds.): 'Book Importance of Biological Parameters of Water Quality to Reform Water Quality Index in Practice’ 2009, edn., pp. 199-204

27 Al-Jeebory, A.A., and Ghawi, A.H.: 'Performance Evaluation of AL-Dewanyia Water Treatment Plant in IRAQ', Al-Qadisiya Journal For Engineering Sciences, 2009, 2, (4), pp. $1-18$

28 AL-Sulaimen, A.M.: 'Evaluation of Potable Water Quality of AL-Diwaniyah Water Treatment Plants', Kufa journal of Engineering, 2014, 1, (1), pp. 40-58

29 Abdal-Hussein, N.A.: 'Evaluation of raw and treated water quality of Hilla River within Babylon province by index analysis', Mesopotamia Environmental Journal, 2015, 1, (5), pp. $16-25$

30 Shakir, E.: 'Assessment of nutrient content of raw water close to water treatment plants located in Baghdad City', Desalination and Water Treatment, 2016, 57, (39), pp. 1822918233

31 Ahmed, M.F.A.-D.: 'Evaluating Study of Tigris River Water Quality and Three Water Treatment Plants within Nineveh Governorate', Tikrit Journal of Engineering Science (TJES), 2016, 23, (1), pp. 105-114

32 Al-Bayatti, K.K., Al-Arajy, K.H., and Al-Nuaemy, S.H.: 'Bacteriological and physicochemical studies on Tigris River near the water purification stations within Baghdad Province', Journal of environmental and public health, 2012, 2012

33 Al-Hashimi, A.M., Al-Bakri, S.A., and Okab, A.A.: 'Assessment of WQI and Microbial pollution for two water treatment plants in Baghdad city', Journal of B abylon University/Engineering Sciences, 2017, 25, (1), pp. 224-235

34 Mohammed, A.B., Goran, S.M.A., and Al-Taee, M.M.: 'The efficiency of drinking -watertreatment processes in removing of some PAHs compounds from water in Erbil city-Iraq', Journal of Thi-Qar Science, 2010, 2, (3), pp. 27-40

35 O'Connor, J.T., O'Connor, T., and Twait, R.: 'Water treatment plant performance evaluations and operations'John Wiley \& Sons, 2009.

36 Smith, S.K., Tayman, J., and Swanson, D.A.: 'State and local population projections: Methodology and analysis'Springer Science \& Business Media, 2006.

37 Karamouz, M., Moridi, A., and Nazif, S.: 'Urban water engineering and management' CRC Press, 2010.

38 Butler, D., and Memon, F.A.: 'Water demand management' Iwa Publishing, 2005.

39 Baroudy, E., Abid, A.L., and Attia, B.: 'Managing Water Demand' IWA Publishing, 2005.

40 Seckler, D.W.: 'World water demand and supply, 1990 to 2025: Scenarios and issues'Iwmi, 1998.

41 Davis, M.L.: 'Water and wastewater engineering’ McGraw-Hill, 2010.

42 McGhee, T.J., and Steel, E.W.: 'Water supply and sewerage’McGraw-Hill New York, 1991. 
43 World Health Organization: 'Measuring chlorine levels in water supplies, Technical Notes on Drinking-Water, Sanitation and Hygiene in emergencies', in Editor (Eds.): 'Book Measuring chlorine levels in water supplies, Technical Notes on Drinking-Water, Sanitation and Hygiene in emergencies' (2002, edn.), pp. 1-4

44 Hossain, M.R.I., and Mamun, M.: 'Estimation of short-term chlorine demand and its correlation with available iron in drinking water', IJCS, 2014, 2, (4), pp. 55-59

45 Edzwald, J.: 'Coagulation in drinking water treatment: particles, organics and coagulants', Water Sci. Technol., 1993, 27, (11), pp. 21-35

\title{
تقييم جودة نوعية المياه والأداء لمحطة معالجة المياه: مدينة خانقين دراسة حالة
}

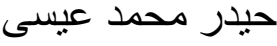 \\ كلية اللغات و العلوم الإنسانية، جامعة كرميان
}

الخلاصة

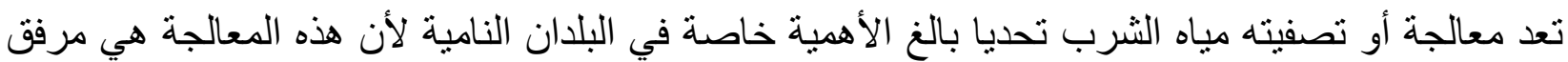

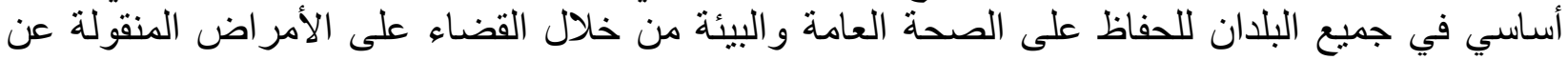

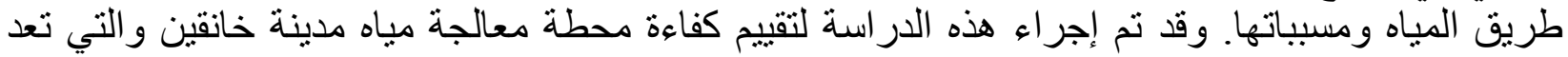

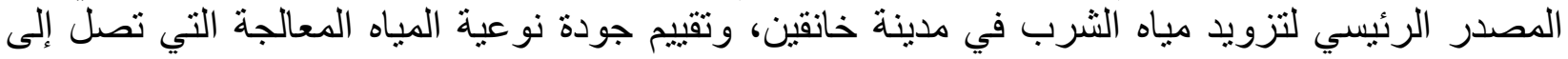

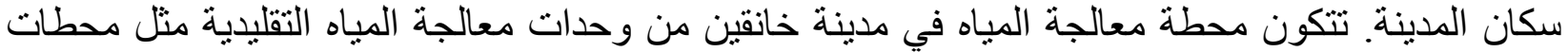

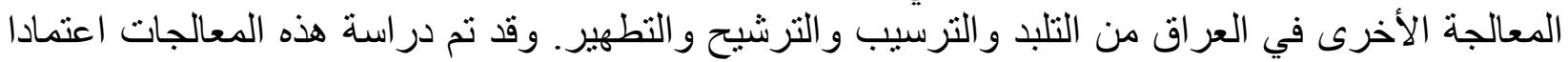

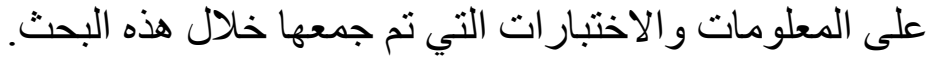

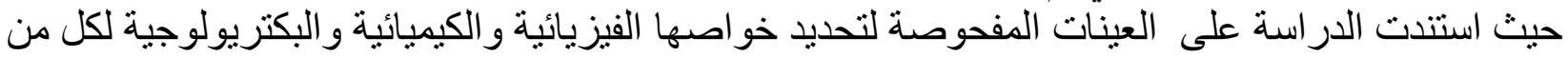

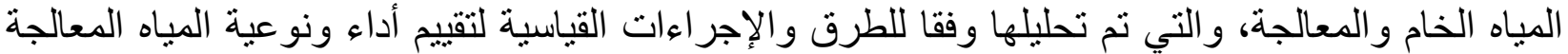

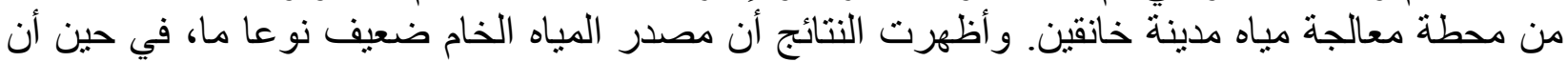

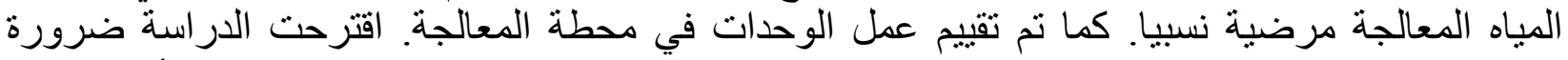

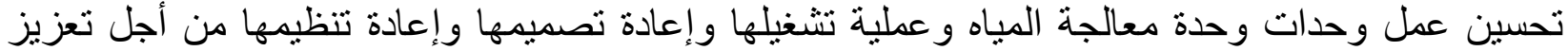

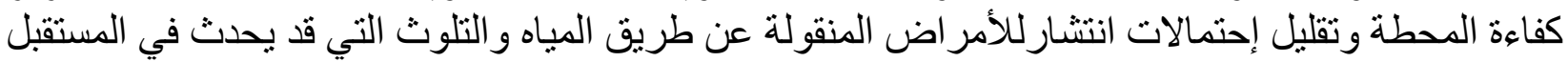
لمياه الثرب في مدينة خانقين.

الكلمات الدالة: أداء محطة مياه، ثقييم جودة مياه الثرب، محطة معالجة المياه، مدينة خانقين 